\title{
ШЛЯХИ ОПТИМІЗАЦІЇ ДОДИПЛОМНОГО НАВЧАННЯ НА КАФЕДРІ АКУШЕРСТВА ТА ГІНЕКОЛОГІї
}

\author{
V. M. Gusiev, V. M. Astachov, Ie. O. Shevchenko \\ Donetsk National Medical University

\section{THE OPTIMIZATION WAYS OF THE PRE-GRADUATE LEVEL IN OBSTETRICS AND GYNAECOLOGY DEPARTMENT}

\begin{abstract}
Мета роботи - підвищити ефективність навчання та якість знань студентів шляхом оптимізації практичної підготовки на додипломному рівні навчання.

Основна частина. У статті наведені сучасні оригінальні технології проведення практичних занять із використанням інтерактивної форми навчальної діяльності. Використання сучасних макетів та муляжів у симуляційному центрі разом із вирішенням імітаційних ситуацій та задач у конкретних клінічних випадках сприятиме більш якісному оволодінню практичними навичками. Стаття присвячена проблемі підвищення ефективності підготовки студентів медичних факультетів на додипломному рівні навчання. Запропоновано впровадження у навчальний процес оригінальних розробок інтерактивних технологій для оптимізації практичної частини занять.

Висновок. Інтерактивні методи навчання дозволяють стимулювати пізнавальну активність студентів, удосконалювати їх практичні навички, що в подальшому буде сприяти клінічному мисленню майбутніх лікарів, дозволятиме об’єктивно оцінювати результати отриманих даних та визначати тактику ведення пацієнта.
\end{abstract}

Ключові слова: додипломна підготовка; симуляційний центр; шляхи оптимізації.

The aim of the work - to increase the efficiency of training and the quality of student knowledge by optimizing practical training at the postgraduate level of education.

The main body. The article presents cutting-edge technologies of conducting practical classes using an interactive form of education. The use of up-to-date models and models in the simulation center, with solving imitative situations and tasks in specific clinical cases will contribute to better practical skills acquirement. The article is about the problem of increasing the efficiency of training medical students at the postgraduate faculty. The implementation of the unique developed interactive technologies for optimization practical part of the lessons is proposed for using.

Conclusion. Interactive teaching methods can stimulate students cognitive activity, improve their practical skills which in the future will contribute to the clinical thinking of future physicians, will allow to evaluate the results of the obtained data and determine the ways of patient treatment.

Key words: pre-graduate training; simulation center; ways to optimize.

Вступ. Реформа медичної освіти в Україні чітко визначає за мету підвищення якості підготовки медичних кадрів шляхом введення ефективної системи організації навчального процесу і гармонізацію вітчизняної медичної освіти з вимогами Європейського Союзу, що на сьогодні стало надзвичайно актуальним до створення та розвитку симуляційних центрів як одного з перспективних шляхів удосконалення системи медичної освіти України [1]. Медичні університети не стоять осторонь цієї програми, проте вони повинні брати більш активну

(c) В. М. Гусєв, В. М. Астахов, Є. О. Шевченко участь у процесах реформування охорони здоров’я, науково обгрунтовуючи ці шляхи та забезпечуючи практичну підготовку відповідних кадрів.

Мета роботи - підвищити ефективність навчання та якість знань студентів шляхом оптимізації практичної підготовки на додипломному рівні навчання.

Основна частина. Базова освіта на рівні вищого навчального закладу (ВН3) є однією з найважливіших умов якості надання медичної допомоги. Підготовка студентів медичного університету є складним, тривалим та затратним процесом. Професія лікаря вимагає не тільки опанування конкретних 
знань із діагностики та лікування, а й обов'язкового оволодіння вміннями на основі отриманих знань. Сучасний студент повинен навчитися вирішувати реальні завдання, оскільки у клінічній практиці кожен пацієнт не подібний до іншого та має індивідуальні особливості наявного патологічного процесу.

Система професійної медичної освіти повинна швидко реагувати на безперервні зміни в науці, зростаючі вимоги до індивідуальних та професійних якостей фахівця і своєчасно вносити необхідні зміни в організацію навчального процесу.

Одна $з$ проблем, яка існує сьогодні, - це контакт студент - пацієнт. Реорганізація методики проведення практичного заняття є основою реформування. Особливістю практичних занять на клінічних дисциплінах є класичний підхід: заняття має будуватись навколо реального пацієнта, що навчає студента клінічно мислити, оцінювати результати отриманих даних та індивідуально призначати лікування. Якість освіти залежить від повноцінності отримуваних знань, відповідних професійним вимогам. 3 цієї точки зору необхідна своєчасна корекція викладачем структури заняття, залучення фахівців стаціонарів та суміжних кафедр $[2,3]$, а також можливість ефективно засвоювати необхідні практичні навички методів обстеження, маніпуляцій та лікування.

Традиційні методи оволодіння практичними навичками на пацієнтах неприйнятні за різних причин. 3 метою якісного навчання на кафедрі акушерства та гінекології Донецького національного медичного університету використовуються функціональні тренажери. Медичні навчальні манекени 3 акушерства та гінекології являють собою реалістичні моделі, які дозволяють засвоїти необхідні практичні маніпуляції, відпрацювати різні прийоми, що застосовуються в акушерстві і гінекології, а також клінічні сценарії, що імітують фізіологічні та патологічні пологи. 3 метою інтенсифікації та підвищення якості освітнього процесу в схему навчання були включені ситуаційні завдання за кожною темою, складені сценарії імітаційних ігор, що моделюють акушерські та гінекологічні

\section{Список літератури}

1. Про вищу освіту : Закон України від 01.07.2014 p. № 1556 -VII.

2. Загальні проблеми та перспективи застосування симуляційних методів освіти / В. М. Лісовий, В. А. Капустник, В. Д. Марковський, І. В. Завгородній // Симуляційне навчання в системі підготовки медичних кадрів : клінічні ситуації, які відпрацьовуються після кожного інформаційного блоку.

Впровадження в навчальний процес симуляційної техніки дозволяє досягти максимального ступеня реалізму клінічного та асоціативного мислення при імітації різних клінічних ситуацій, а також відпрацювати практичні навички окремих діагностичних та лікувальних маніпуляцій [3]. Вирішення цього питання має принципове значення для повноцінного оволодіння навчальною програмою, особливо її практичної частини на клінічній кафедрі.

Перевагами симуляційного тренінгу є можливість отримання практичного досвіду у віртуальному середовищі без ризику для пацієнта, зниження стресової реакції під час перших самостійних маніпуляцій, необмежена кількість повторів для відпрацювань навичок, можливість відпрацювання дій при рідкісних та таких, що загрожують життю, патологіях. Тренінг відбувається незалежно від розкладу роботи клініки; частину функцій викладача бере на себе віртуальний тренажер. Робота у симуляційному класі також сприяє розвитку як індивідуальних умінь і навичок, так і здатності командної взаємодії [2, 3].

Висновок. Роль вищих медичних навчальних закладів України у процесі реформування медичної галузі полягає в забезпеченні викликів сьогодення щодо підготовки лікаря нової якості, який повинен бути насамперед готовим до роботи в умовах запровадження страхової медицини. Реорганізація навчального процесу в університеті вимагає удосконалення методики проведення практичного клінічного заняття із забезпеченням якісними методичними та наочними засобами навчання, організації самостійної клінічної роботи студента, зменшення кількості студентів на одного викладача, особливо при вивченні клінічних дисциплін тощо. Використання симуляційних центрів, як одного з методів реорганізації навчального процесу, буде сприяти оптимізації оволодінню практичними навичками та підвищувати інтерес майбутніх лікарів до професії.

матеріали L навч.-метод. конф., присвяченої 212-й річниці від дня заснування ХНМУ, Харків, 30 листопада 2016 р. - Харків, 2016. - С. 3-7.

3. Булавенко О. В. Досвід застосування симуляційних технологій у навчальному процесі спеціалізованого акушерсько-гінекологічного кластера на базі Вінницького 
національного медичного університету ім. М. І. Пирогова / О. В. Булавенко, Д. Г. Конькова, І. Л. Кукуруза // Шляхи удосконалення навчального процесу і необхідність впровадження нових підходів у роботі кафедр ме- дичного університету в сучасних умовах : тези доповідей навч.-метод. конф., Вінниця, 26 лютого 2014 р. - Вінниця, 2014. - С. 18-19.

3. Bulavenko, O.V., Konkova, D.H., \& Kukuruza, I.L. (2014). Dosvid zastosuvannia symuliatsiinykh tekhnolohii u navchalnomu protsesi spetsializovanoho akusherskohinekolohichnoho klastera na bazi Vinnytskoho natsionalnoho medychnoho universytetu im. M.I. Pyrohova [The experience of using simulation technologies in the educational process of a specialized obstetric and gynecological cluster based on the Vinnytsia National Medical University by M.I. Pyrohov]. Tezy dopovidei navchalno-metodychnoi konferentsii - Abstracts of the Reports of the Educational-methodical Conference [in Ukrainian].

Отримано 05.02.18

Електронна адреса для листування: 54.145green@gmail.com 